\title{
Penerapan Konsep Ta'dib dalam Pembelajaran Ekonomi Syariah
}

\author{
Rahmad Hakim \\ Program Studi Ekonomi Syariah, Fakultas Agama Islam, \\ Universitas Muhammadiyah Malang \\ E-mail: rahmadhakim@umm.ac.id
}

\begin{abstract}
Increasing awareness of Muslims associated with the awareness of the economy in accordance with Islamic values is good news to be grateful. This has the logical consequence that the development of Islamic economics both in the theoretical and practical level is increasing rapidly in proportion to the increasing awareness of Muslims, especially in Indonesia. This study aims to analyze in depth and comprehensively related three important points, namely: first, the concept of ta'dib in Islam. Second, the economic values of sharia economy. Third, the relevance of the concept of ta'dib in Islamic economics. The approach used in this study is literature research by conducting a study and indepth analysis related to literature related to the concept of $t a^{\prime}$ 'dib and Islamic economic values. The result shows that the concept of $t a$ ' $d i b$ can be applied in the study of Islamic economic accordance with the key concept which stated in the al-Qur'an such as: al-fadlu, 'adl, maslahah, iqtishad, dan falah. Using those values so that the activity has the motivation (intention) is right and good that is reaching mardhatillah. On the other hand, running an economic activity based on true and good Islamic values is a form of a Muslim's presence against the virtue (al-fadlu) given by Allah to him.
\end{abstract}

Keywords: ta'dib, Islamic economics, Islamic economics teaching

\section{Pendahuluan}

Berbagai kerusakan yang terjadi di bumi ini disebabkan perbuatan manusia sendiri. Perbuatan manusia terbsebut tentu berdasarkan cara pandangnya (worldview) terhadap dunia dan diri sendiri, berkaitan dengan pemenuhan keinginan yang tidak terbatas dengan sumber daya alam yang terbatas. Meskipun pendapat ini dianggap 'benar' pada umumnya, namun pendapat ini tidak boleh diambil bulat-bulat tanpa adanya kritik terhadap pendapat tesebut. Jika sistem kapitalis menyatakan bahwa 'wealth is the measure of everyting' -modal adalah 
ukuran segala sesuatu, atau modal adalah segala-galanya. Dengan demikian, individu yang memiliki wealth inilah yang cenderung akan berkuasa atas segala faktor-faktor produksi seperti sumber daya alam, pekerja dan teknologi. Sebaliknya, sistem ekonomi sosialis, walaupun perlahan mulai ditinggalkan, menyatakan bahwa 'equality is the measure of everyting' -kesetaraan dan persamaan adalah ukuran segala sesuatu, jika tidak sama maka hal inilah yang perlu 'dibongkar' entah dengan apapun caranya. Implikasinya, sistem ini akan cenderung mereduksi talenta, keaahlian dan potensi yang dimiliki oleh individu sebab yang diakui hanyalah kolektivitas untuk kebersamaan guna memenuhi persamaan dalam pendapatan. Menurutnya, inilah sejatinya kesejahteraan -sama rasa, sama rata. Cara pandang yang dimiliki oleh kedua sistem diatas ada baiknya, namun banyak keburukanya. Buktinya, realitas yang terjadi sekarang justru banyak kerusakan yang ditimbulkan dari pada manfaat yang diberikan. Kesenjangan semakin besar, krisis sering terjadi, pengangguran semakin banyak, ekonomi semakin susah, dan praktik kecurangan terjadi dimana-mana; yang demikian inilah seringkali dinamakan fenomena loss of adab dalam lingkup ekonomi.

Menggeliatnya kesadaran ummat Muslim mengenai pentingnya sistem ekonomi yang sesuai dengan nilai-nilai Islam yang tertera dalam al-Qur'an dan hadist menjadikan ekonomi syariah tumbuh begitu pesat. Sebagian menganggap bahwa keberadaan ekonomi syariah akhir -akhir ini sebagai alternatif solusi untuk kegagalan dua sistem ekonomi diatas. Sebagian lagi menganggap bahwa ekonomi syariah bukanlah alternatif, sebab sudah ada dalam al-Qur'an 1437 tahun yang lalu. M. Umer Chapra menyatakan beberapa fungsi dari ekonomi syariah, antara lain: Pertama, mempelajari perilaku aktual individu maupun kelompok (pasar, pemerintahan dan perusahaan dengan pendekatan yang lebih komprehensif (kaffah) antara aspek individu dan masyarakat, pemenuhan kebutuhan materil dan non-materil. Kedua, memberikan advise terkait praktik ekonomi yang 'seharusnya' dilakukan sesuai dengan tuntunan syariah Islam dalam al-Qur'an dan hadist. Ketiga, penjelasan komprehensif sebab-sebab penyimpangan dan seruan untuk kembali ke 'jalan yang benar'. Keempat, memberikan strategi untuk perubahan sosioekonomi dan politik untuk merealisasikan tujuan.Meminjam Istilah Ibnu Taymiyyah, "As-siyasah as-syar'iyyah fi islahi ar-ra'iy wa arra'iyyah" -strategi syar'i guna memperbaiki para pemimpin dan masyarakatnya. ${ }^{1}$ Tulisan ini akan memaparkan tentang penerapan konsep ta'dib dalam pengajaran ekonomi syariah. Penerapan ini dianalisa secara mendalam melalui konsepkonsep kunci yang relevan dengan kegiatan ekonomi semisal al-fadlu, 'adl, maslahah, iqtishad, dan falah. Sehingga, diharapkan akan memberi penjelasan yang kongkrit terkait penerapan $t a$ 'dib dalam pengajaran ekonomi syariah.

\footnotetext{
${ }^{1}$ M. Umer Chapra, Masa Depan Ilmu Ekonomi: Sebuah Tinjauan Islam, terj. Ikhwan Abidin Basri, (Jakarta: Geman Insani Press, 2001), 109-110
} 


\section{Review Konsep Ta'dib dalam Pendidikan Islam}

Kata 'ta'dib' berasal dari arab istilah adaba - yu'addibu berarti mendidik dan membiasakan. Sedangkan secara istilah diartikan sebagai upaya pembiasaan diri untuk melakukan tindakan dan perilaku yang baik. ${ }^{2}$ Seiring berjalannya waktu. Kata ini bermetamorfosa menjadi sebuah konsep salam pendidikan Islam. Imam al-Ghazali dalam menyatakan bahwa inti utama dari pendidikan adalah menyempurnakan akhlak (tahdib al-Akhlaq).Dinyatakan bahwa akhlak adalah suatu sikap yang mengakar dalam jiwa, yang darinya lahir berbagai perbuatan yang bersifat spontan dan reflek, tanpa perlu pemikiran panjang dan pertimbangan.Jika dari sikap spontanitas dan reflektif ini seseorang melahirkan perbuatan baik dan terpuji, maka seseorang tersebut dapat dikatakan memiliki akhlak yang baik; begitupula jika terjadi sebaliknya. ${ }^{3}$ Latar belakang mengapa konsep ta'dib digunakan adalah karena pendidikan dalam Islam, atau bahkan agama-agama lain, bertujuan untuk menjadikan keberhasilan individu dan kebahagiaan hidup dunia (maslahah) dan akhirat (falah) sebagai cita-cita dan tujuan pendidikan yang terpenting. ${ }^{4}$

Menurut Al-Attas, inti dari pendidikan dalam Islam bukanlah untuk menghasilkan warga Negara dan pekerja yang baik. Akan tetapi pendidikan tersebut bertujuan untuk menciptakan manusia yang baik. Sebagaimana dijelaskan, bahwa tujuan mencari ilmu adalah untuk menanamkan kebaikan ataupun keadilan dalam diri manusia sebagai seorang manusia dan individu, bukan hanya sebagai seorang warga Negara ataupun anggota masyarakat. Penekanan lebih dinyatakan bahwa tujuan pendidikan Islam adalah nilai manusia sebagai manusia sejati, sebagai warga kota, sebagai warga Negara dalam lingkup kecil, sebagai sifat yang spiritual yang tidak hanya diukur dalam entitas fisikpragmatis-utilitarian semata. ${ }^{5}$ Lebih lanjut, penekanan pendidikan jika ditujukan kepada individu akan berimplikasi kepada pengetahuan tentang akal, nilai, jiwa, tujuan, dan hikmah yang sebenarnya dari kehidupan. Sebab akal, nilai, dan jiwa adalah unsur yang inheren pada setiap individu. Sebaliknya, jika pendidikan ditekankan kepada masyarakat dan Negara, akan mengakibatkan sekularisme, termasuk didalamnya ideologi dan pendidikan sekuler. ${ }^{6}$

Penggunaan istilah 'ta'dib' dianggap lebih akurat dan tepat, disebabkan karena beberapa hal; pertama, telah bergesernya arti kata tarbiyah, ta'lim dan ta'dib dari arti yang sebenarnya yang berlaku dimasa lampau, sedangkan masa kiniartinya

\footnotetext{
${ }^{2}$ Sulaiman MH Boayo, Idea of Thaqāfah and Culture in the Muslim dan Western Conception, World Journal of Islamic History and Civilization, Vol. 1 No.2, 2011, 76

${ }^{3}$ Abidin Ibn Ruslan, Pemikirian al-Ghazali Tentang Pendidikan, Cet.I, (Yogyakarta: Pustaka Pelajar, 1998), 93

${ }^{4}$ Wan Mohd Nor Wan Daud, Filsafat dan Praktik Pendidikan Islam Syed Naquib Al-Attas, terj. Hamid Fahmy dkk, Cet.I, (Bandung: Mizan, 2003), 165

5 Ibid, Wan Mohd Nor Wan Daud, Filsafat dan Praktik Pendidikan Islam Syed Naquib AlAttas.., 165

${ }^{6}$ Ibid, Wan Mohd Nor Wan Daud, Filsafat dan Praktik Pendidikan.., 165
} 
menjadi lebih terbatas. Kedua, struktur dari konsep ta'dib sudah mencakup unsurunsur 'ilm (ilmu), ta'lim (instruksi), dan tarbiyah (pembinaan yang baik). Berdasarkan dua hal tesebut, maka adab menurut Al-Attas dapat diartikan sebagai, "pengenalan dan pengakuan terhadap realitas bahwasanya ilmu dan segala sesuatu yang ada (termasuk hewan, tumbuhan dan bangunan) terdiri dari hierarki yang sesuai dengan ketegori-kategori dan tingakatan-tingkatanya, dan bahwa seseorang itu memiliki tempatnya masing -masing dalam kaitannya dengan realitas, kapasitas, potensi fisik, intelektual dan spiritualnya”. Sebagai contoh, adab terhadap diri sendiri dan sesama masyarakat (muamalah). Jika adab kepada diri sendiri bermula ketika seseorang mengakui bahwa dirinya terdiri dari dua unsur, yaitu akal dan hawa nafsu (sifat-sifat kebinatangan). Ketika akal seseorang dapat menguasai dan mengontrol hawa nafsunya, maka dapat dikatakan ia sudah beradab karena meletakkan keduanya pada tempat yang benar. Keadaan seperti itu adalah keadilan bagi dirinya, jika melakukan sebaliknya maka ia telah berbuat tidak adil (zalim) kepada dirinya sendiri. ${ }^{7}$

Sementara itu, adab dalam konteks muamalah dengan sesama manusia, berarti norma-norma etika yang diterapkan dalam tata karma sosial sudah sepatutnya memenuhi beberapa syarat yang didasarkan pada posisi seorang, misalnya dalam keluarga dan masyarakat. Dalam hal ini, posisi seseorang bukanlah ditentukan oleh manusia berdasarkan kriteria kekuatan, kekayaan, ataupun keturunan. Melainkan ditentukan oleh kriteria yang ditetapkan dalam Al-Qur'an berdasarkan kriteria keimanannya, keilmuanya, pemikiarannya, dan kemuliaan perbuatannya (taqwa). Jika dengan tulus menunjukkan sikap rendah hati, kasih sayang, hormat, peduli dan lain-lain kepada orangtua, saudara, anak-anak, tetangga, dan pimpinan masyarakatnya. Hal itu menunjukkan bahwa seseorang mengetahui tempatnya yang sebenarnya dalam hubungannya dengan manusia lainnya.

\section{Ekonomi, Iqtishad dan Ekonomi Syariah}

Sebagaimana telah diketahui, bahwa istilah ekonomi sendiri berasal dari akar kata latin, yaitu 'ecos' dan 'nomos'. Kata 'ecos' berarti ilmu pengetahun, sedangkan 'nomos' rumah tangga. Jika disintesiskan menjadi 'ilmu pengetahuan yang mempelajari tentang masalah ke-rumah tangga-an'. Sedangkan secara istilah dalam encyclopedi britanicca didefinisikan sebagai, "social science that seeks to analyze and describe the production, distribution, and consumption of wealth". 8 Yang menjadi masalah adalah, tidak sedikit dari kita atau mungkin institusiinstitusi perguruan tinggi baik di Indonesia maupun di belahan dunia manapun, selalu menterjemahkan kata 'economics' (bahasa inggris) atau ekonomi (bahasa melayu-indonesia) ke dalam bahasa arab dengan kata iqtishad. ${ }^{9}$ Padahal dalam bahasa arab, istilah iqtishad ini artinya bukanlah ilmu pengetahuan tentang rumah

\footnotetext{
${ }^{7}$ Ibid, Wan Mohd Nor Wan Daud, Filasafat dan Praktik Pendidikan, 178

${ }^{8} \mathrm{http} / / / \mathrm{www}$.britannica.com/topic/economics. diakses, Senin, 09 Nopember 2015, 13:10 WIB

${ }^{9}$ Antonim dari istilah ini adalah 'isrāf' berlebih-lebih dan 'at-taqtīr' pelit.
} 
tangga, akan tetapi merupakan suatu tindakan atau kondisi pertengahan, proporsional dan tidak berlebihan dan tenang dalam melakukan sesuatu(al-qashdu fi as-syai'), antonimnya adalah al-ifrat tergesa-gesa, khususnya adalah pertengahan dalam melakukan pengeluaran (al-qashdu fil ma 'isyah aw al-infaq). ${ }^{10}$ Disinilah letak inkonsistensi penggunaan kata menjadi problem.

Sementara itu, istilah iqtishad berasal dari akar kata arab 'qasada-yaqsuduiqtishad' yang berarti, bertujuan, pertengahan dan proporsional. Sedangkan secara istilah, iqtishad dapat diartikan sebagai suatu tindakan atau kondisi pertengahan, proporsional dan tidak berlebihan dalam melakukan sesuatu, utamanya adalah pertengahan dalam melakukan pengeluaran (infaq). ${ }^{11}$ Lawan kata (antonim) dari iqtishad adalah bermegah-megah (tabdzir) dan pelit (taqtir). Secara hipotesis (praduga) saja, mungkin kata iqtishad jarang tertulis dalam ayat-ayat al-Qur'an dan sanad hadist, atau frequensi jumlah kata iqtishad yang tertulis dalam alQur'an tidak sebanyak frekuensi jumlah kata tabdzir atau mungkin kata yang semakna (sinonim) darinya, yaitu israf. Akan tetapi, perlu diingat bahwa dimanapun terdapat dua kata ini, pasti didahulu dengan huruf ' $l a$ ' yang berarti larangan. Dengan demikian, jika digabungkan, maka kata 'la-tubadzir' atau 'latusrifu' secara tekstual berarti 'jangan berlebihan', sedangkan secara kontekstual artinya adalah 'iqtishad' yaitu proporsional dan pertengahan. Disinalah mungkin ajaran Islam dalam ber-ekonomi, yaitu agar seorang Muslim bertindak tidak berlebihan, pertengahan dan proporsional.

Lantas bagaimana dengan ekonomi syariah atau ekonomi Islam? Seperti yang telah diketahui sebelumnya, mengenai arti dari kata 'economics' atau 'ekonomi'. Disini akan dicoba menjabarka kata Islam saja. Kata 'Islam' berasal dari akar kata bahasa arab, 'aslama-yuslimu' yang berarti patuh tunduk dan berserah diri. Dapat juga didasarkan kepada kata, 'salima-yaslamu' yang berarti damai, tentram, dan menyelamatkan (bermanfaat). Dengan demikian istilah ini mengandung dua dimensi; pertama, dimensi vertikal (ibadah -hubungan manusia dengan Allah Swt.), yaitu tunduk, patuh dan berserah diri kepada sang maha pencipta. Kedua, dimensi horizontal (muamalah -hubungan manusia dengan manusia, hewan dan tumbuhan 'semesta alam'), yaitu menebar kedamaian, dan ketentraman bagi manusia lain, hewan dan tumbuhan. Singkat kata, makna dari kata ini dekat dengan kata arab 'islah' atau 'maslahah' -berarti kebaikan, perbaikan atau kemanfaatan. Lawan katanya (antonimnya) adalah 'fasad' atau 'mafsadah'berarti kerusakan, perusakan dan membahayakan. Dengan demikian, jika kata 'ekonomi' dan 'syariah atau 'Islam' digabungkan, maka ekonomi Islam atau ekonomi syariah adalah 'ilmu pengetahuan yang mempelajari tentang masalah kerumah tangga-an, berdasarkan cara pandang (worldview) Islam dan Syariah; yaitu

${ }^{10}$ Ibnu Mandzur, Lisan al-'Arab, tahqiq. 'Abdullah 'Ali al-Kabir et, al., (Qahirah: Dar alMa'arif li an-Nasyr, t.t.), 3642

11 Anis Byarwati \& Tjiptohadi, Ekonomi Islam atau Iqtishad?, Jurnal Ekonomi, Manajemen dan Akuntansi Islam, Vol.1, No.1, 2013, 15 
ibadah- dengan pasrah, tunduk dan berserah diri kepada Allah Swt. Dan muamalah -menebar kebaikan, perbaikan dan kemanfaatan di alam semesta. Dalam ekspresi al-Qur'an disebutkan, 'Rahmatan li al- 'Alamin'. Singkat kata, mengurus masalah rumah tangga diniatkan dengan ibadah dan muamalah. Mengurus masalah dunia dengan tidak melupakan akhirat. Sembari mencari ilmu dan beramal, tidak melupakan keimanan. Dengan demikian, antara iqitishad dan ekonomi syariah sebenarnya adalah semakna, beda istilah. Semakna, sebab yang pertama dan kedua bertujuan untuk merefleksikan perintah Allah Swt. yang bermuara kepada satu istilah yaitu keadilan sekaligus ketakwaan. Sebab dalam alQur'an direfleksikan “i'dilu huwa aqrabu li at-Taqwa” -berbuat adil lah, karena perbuatan itu mendekati kepada ketakwaan.

Jika iqtishad adalah adil dengan tidak berlebihan dan melampaui batas. Maka ekonomi syariah adalah adil dengan tidak memisahkan antara aspek dunia dan akhirat.Tidak berbuat kerusakan, dan menyebarkan kebaikan dan perbaikan. Adil dengan tidak memisahkan antara aspek ibadah dan muamalah. Bukankah termasuk didalamnya nilai-nilai iqtiahad?, dengan meletakkan dunia dan akhirat sesuai dengan proporsi masing -masing, dan juga meletakkan urusan keduniaan berada pada aspek ibadah sekaligus muamalah (pertengahan). Diawal periode Islam, Sayyidina Abu Bakar khalifah pertama setelah Rasulullah Saw. wafat, mengekspresikannya dengan kata, "Wallahi, aku tidak akan rela jika ada yang memisahkan antara shalat dengan zakat"12 -dengan kata lain, beliau tidak akan rela, jika ada yang memisahkan antar aspek ibadah dan muamalah, aspek akherat (ukhrawi) dan keduniaan (duniawi); sebab perilaku tersebut adalah kedzoliman dan ketidakadilan

Dengan ekspresi lebih kontemporer, Al-Attas menyatakannya bahwa segala sesuatu harus dilihat dengan penglihatan eksternal (dzahir) dan internal (bathin). Jika yang pertama merefleksikan aspek inderawi keduniaan, aspek yang lain merefleksikan aspek non-inderawi keakhiratan. Itulah cara pandang Islam terhadap dunia, 'the worldview of Islam' ${ }^{13}$ Dengan menitikberatkan pada aspek dzahir yang terlihat saja, kemudian meninggalkan aspek bathin. Tindakan seperti ini juga merupakan refleksi dari kedzaliman dan ketidak adilan. Bukankah Allah telah berfirman, 'I'dilu huwa aqrabu li at-taqwa' -berbuat adillah, karena perbuatan adil itu mendekati kepada ketakwaan (QS. Al-Ma'idah[5]: 8).

\section{Beberapa Konsep Kunci dalam al-Qur'an}

Implikasi konsep ta'dib dalam ekonomi syariah tentu tidak dapat dilihat kecuali dengan menganilisis secara mendalam istilah-istilah atau konsep-konsep kunci dalam dalam Al-Qur'an yang berkaitan dengan kegiatan ekonomi. Sepanjang pengetahuan penulis, beberapa konsep kunci yang dianggap relevan dengan

\footnotetext{
${ }^{12}$ Ekspresi ini adalah refleksi atas pemisahan sebagian kaum Muslimin antara shalat dengan zakat (baca; sekulerisme zaman klasik)

${ }^{13}$ Ekspresi yang kedua adalah refleksi atas sekulerisme zaman modern
} 
ekonomi meliputi; al-fadlu (keutamaan), al-Iqtishad (pertengahan), al-'Adlu (keadilan), falah (kemenangan) dan maslahah (kemanfaatan).

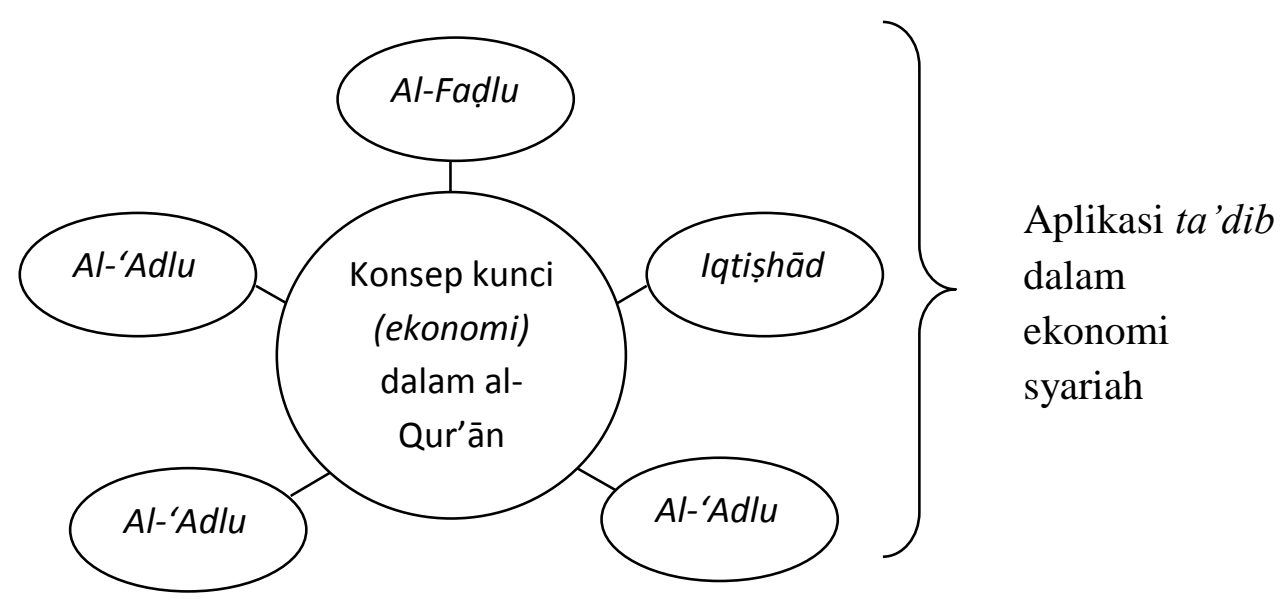

\section{1. $A l$ - Fadlu (keutamaan)}

Kata yang berdimensi ekonomi dalam al-Qur'an adalah kata al-fadlu. Ibnu Mandzur dalam Lisan al- 'Arab memberikan definisi istilah al-fadlu, fadhala, alfadhilah, sebagai lawan kata (antonim) dari kondisi kurang dan kekuranganbatau derajat tertinggi dalam keutamaan. ${ }^{14}$ Dimuliakan karena beberapa sebab; pertama, dimuliakan dengan kedewasaan dengan akalnya (tamyiz) -karena dapat membedakan mana yang baik dan buruk, yang halal dan yang haram. Kedua, dimuliakan atas makhluk lainnya; hewan dan tumbuhan dengan akal. Jika manusia berjalan dengan berdiri sementara hewan dengan melata, atau merangkak. Berdasarkan makna al-fadlu diatas, maka bergeser kepada makna yang selanjutnya dari struktur huruf yang sama yaitu tafaddhala yang berarti apabila dia mendapatkan (sesuatu) dengan keutamaannya, dan dia berlaku baik terhadapnya. Demikian ini dinamakan perilaku al-ifdhal ataupun al-ihsan. Sebagaimana Allah berfirman; "Wa yu'thi kullu dzi fadlin fadlahu”-barang siapa yang mempunyai keutamaan terhadap agamanya, maka Allah akan memberikan keutamaan dalam hal pahala, dan diutamakan beberapa derajat di dunia karena agamannya. ${ }^{15}$ Semisal keutaamaanyang diberikan kepada sahabat Rasulullah. Saw. Maksud dari diutamakan atau dilebihkan seseorang dari makanan dan yang lainnya adalah jika meninggalkan atau memberikan sebagian dari [harta] hartanya kepada orang yang membutuhkan.

\subsection{Falah (kemenangan)}

${ }^{14}$ Ibid, Ibnu Mandzur, Lisan al- 'Arab.., 3428

15 (QS. Hud[11]: 3) 
Falah berasal dari istilah arab dari kata kerja aflaha-yuflihu yang berarti kesuksesan, kemulian atau kemenangan. Secara istilah, falah adalah kemuliaan dan kemenangan dalam kehidupan. Istilah ini diambil dari isitlah dalam al-Qur'an yang sering dimaknai sebagai keberuntungan jangka panjang didunia dan akhirat, sehingga tidak hanya memandang aspek material akan tetapi lebih menekankan aspek spiritual.

Dalam semua sistem ekonomi yang eksis sekarang ini seperti kapitalis, sosialis dan komunis, asumsi utama yang digunakan ialah bahwa manusia mempunyai cita-cita untuk mencapai kesejahteraan ekonomi di dunia semaksimal mungkin.Keuntungan manusia di akhirat adalah tidak relevan dan tidak pernah 'dihiraukan'dalam penyusunan dasar dan strategi dalam sistem-sistem ekonomi diatas. Sistem-sistem ekonomi yang berbeda itu ada disebabkan karena perbdeaan ideologi masing-masing dalam menetukan cara terbaik bagi guna mencapai kesejahteraan. Sebagai contoh, Negara-negara yang berpegang kepada ideologi kapitalis meyakini bahawa cara dan pendekatan terbaik mencapai ksejahteraan ekonomi adalah melalui pasaran bebas. Sedangkan Negara-negara yang berideologi sosialis dan komunis percaya bahwa pendekatan terbaik untuk mencapai kesejahteraan tersebut ialah melalui ekonomi perencanaan terpusat. Sistem ekonomi syariah berbeda dari sistem-sistem ekonomi diatas baik dari aspek metode atau pendekatannya, tetapi juga dari segi tujuan hidup manusia itu sendiri.Hal ini disebabkantujuan hidup manusia menurut Islam adalah untuk beribadah kepada Allah dalam segala bidang kehidupan guna mencapai falah kemenangan dunia dan akhirat. Ibadah yang dimaksudkan adalah segala aktivitas yang dilakukan berdasarkan peraturan yang ditentukan oleh Allah. Ibadah yang demikian termasuk ibadah-ibadah khusus seperti shalat, puasa, zakat, haji, zikir dan lain-lain; dan juga ibadah-ibadah umum yang berkaitan dengan berbagai bagai aktivitas kehidupan seperti ekonomi, sosial, politik dan seterusnya. Maka konsep ibadah dan falah bermakna luas dalam Islam. Kegiatan dalam bidang ekonomi yang berdasarkan prinsip-prinsip Islam juga termasuk ke dalam konsep ibadahyang dengannya, manusia akan mencapai falah. Kemenangan yang berbentuk kesejahteraan ekonomi di dunia ini hanya merupakan sebagian kecil dari konsep falah, karena kemenangan yang sebenarnyaadalah diakhirat nanti. Tegasnya, tujuan hidup manusia menurut Islam jauh lebih komprehensif dari apadisebutkan dalam ekonomi konvensional. Manusia yang dikehendaki oleh Islam bukanlah manusia ekonomi (economic man) tetapi manusia Islam (Islamic man). ${ }^{16}$

Muhammad Akram Khan telah malakukan pecobaan untuk menjelaskan aspek falah ini dalam lingkup ekonomi Islam. Menurut beliau, aspek falah dapat dibagi dalam empat (4) ruang lingkup; pertama, kelangsungan hidup. kedua, kebebasan

\footnotetext{
${ }^{16}$ Ja'far Ahmad et, al., Ekonomi Islam: Suatu Pendekatan Analisis, (Bangi, UKM Press, 2011), $40-41$
} 
berkeinginan. ketiga, kekuatan dan harga diri. keempat, spiritualitas. kesemuanya beliau jabarkan mulai dari aspek mikro (individu) maupun aspek makro (kelompok). Namun penulis tidak sependapat dengan beliau, hal ini disebabkan karena pembagian tersebut hanya dalam aspek materi dan duniawi. Padahal jika kita merujuk kepada raison d erte dari istilah falah itu sendiri adalah mencakup kemenangan didunia dan akhirat. Bahkan kemenangan ukhrawi lebih dominan dibanding duniawi. Menurut penulis, kemenangan duniawi adalah maslahah, yang nanti akan membawa kepada falah,sebab berkaitan dengan aspek materil. Sebaliknya, kemenangan ukharwi inilah yang disebut falah. Dengan demikian, apa yang dikemukakan oleh Akram Khan diatas lebih relevan jika ditempatkan kepada bahasan maslahah bukan falah. Karena falah berkaitan dengan aspek nonmateril yaitu ukhrawi.

Aspek Mikro dan Makro dalam Falah menurut Islam

\begin{tabular}{|c|c|c|}
\hline Unsur Falah & Aspek Mikro & Aspek Makro \\
\hline \multirow[t]{4}{*}{ Kelangsungan Hidup } & $\begin{array}{l}\text { Kelangsungan hidup biologis; } \\
\text { kesehatan, kebebasan, keturunan }\end{array}$ & $\begin{array}{l}\text { Keseimbangan ekologi dan } \\
\text { lingkungan }\end{array}$ \\
\hline & $\begin{array}{l}\text { Kelangsungan hidup ekonomi; } \\
\text { kepemilikan faktor produksi }\end{array}$ & $\begin{array}{l}\text { Pengelolaan SDA dan } \\
\text { Penyediaan kesempatan berusaha } \\
\text { untuk seluruh penduduk }\end{array}$ \\
\hline & $\begin{array}{l}\text { Kelangsungan hidup sosial; } \\
\text { Persaudaraan dan harmonisasi } \\
\text { hubungan sosial }\end{array}$ & $\begin{array}{l}\text { Kebersamaan sosial, ketiadaan } \\
\text { konflik antar kelompok }\end{array}$ \\
\hline & $\begin{array}{l}\text { Kelangsungan hidup politik; } \\
\text { Kebebasan dalam berpartisipasi } \\
\text { politik }\end{array}$ & Jati diri dan kemandirian \\
\hline \multirow[t]{2}{*}{ Kebebasan Berkeinginan } & Terbebas dari kemiskinan & $\begin{array}{l}\text { Penyediaan sumber daya untuk } \\
\text { seluruh penduduk }\end{array}$ \\
\hline & Kemandirian hidup & $\begin{array}{l}\text { Penyedian sumber daya untuk } \\
\text { generasi yang akan datang }\end{array}$ \\
\hline \multirow[t]{2}{*}{ Kekuatan dan harga diri } & Harga diri & $\begin{array}{l}\text { Kekuatan ekonomi dan } \\
\text { kebebasan dari utang }\end{array}$ \\
\hline & $\begin{array}{l}\text { Kemerdekaan, perlindungan } \\
\text { hidup dan kehormatan }\end{array}$ & Kekuatan militer \\
\hline Spiritualitas & $\begin{array}{l}\text { Tauhid, ikhlash, jujur, zuhud, } \\
\text { syukur, sabar, ketenangan, } \\
\text { akhlak yang baik kepada semua } \\
\text { makhluk. }\end{array}$ & $\begin{array}{l}\text { Kemandirian, Profesioniltas } \\
\text { dalam pekerjaan, tauhid sosial, } \\
\text { etos kerja, kemajuan IPTEK } \\
\text { berdasar wahyu ilahi }\end{array}$ \\
\hline
\end{tabular}

Sumber:M.Akram Khan (1994). An Introduction to Islamic Economic, Islamabad: III T Pakistan

\subsection{Maslahah (kemanfaatan)}

Istilah maslahah berasal dari akar bahasa arab salaha yang berarti kebaikan atau manfaat dan kedamaian antonim dari al-fasad yang berarti kerusakan. Dalam bentuk lainnya, as-sulhu semakna denganas-silmu. Jika demikian, maka berbuat baik sama dengan berbuat keselamatan. Maka, seorang yang berbuat sesuatu kebaikan adalah seseorang yang telah melaksanakan nilai-nilai Islam. Dan suatu keharusan bagi seorang Muslim untuk melakukan suatu hal yang bermanfaat untuk dirinya sendiri maupun orang lain. ${ }^{17}$

Kehidupan yang mulia dan sejahtera di dunia dan akhirat (falah), dapat terwujud apabila terpenuhi kebutuhan-kebutuhan hidup manusia secara seimbang. Tercukupinya kebutuhan masyarakat akan memberikan dampak yang disebut

\footnotetext{
${ }^{17}$ Ibid, Ibnu Mandzur, Lisan al- 'Arab.., 2479
} 
dengan maslahah. Maslahah adalah segala bentuk keadaan, baik material maupun nonmaterial, yang mampu meningkatkan kedudukan manusia sebagai makhluk yang paling mulia. Menurut as-Syatibi, maslahah dasar bagi kehidupan manusia terdiri dari lima hal, yaitu agama (din), jiwa (nafs), intelektual ('aql), keluarga dan keturunan (nasl), dan harta(mal). Kelima hal tersebut merupakan kebutuhan dasar manusia, yaitu kebutuhan yang mutlak harus dipenuhi agar manusia dapat hidup bahagia di dunia dan akhirat. Jika salah satu dari kebutuhan diatas tidak terpenuhi atau terpenuhi dengan tidak seimbang niscaya kebahagiaan hidup juga tidak tercapai dengan sempurna.

Islam mengajarkan agar manusia menjalani kehidupannya secara benar, sebagaimana telah diatur oleh Allah.Bahkan, usaha untuk hidup secara benar dan menjalani hidup secara benar inilah yang menjadikan hidup seseorang bernilai tinggi.Ukuran baik buruk kehidupan sesungguhnya tidak diukur dari indikatorindikator lain melainkan dari sejauh mana seorang manusia berpegang teguh kepada kebenaran dalam hidup, yaitu agama (din). Seorang muslim yakin bahwa Islam adalah satu-satunya agama yang benar dan diridhai Allah. Islam telah mencakup seluruh ajaran kehidupan secara komprehensif. Jadi agama merupakan kebutuhan manusia yang paling penting.Islam mengajarkan bahwa agama bukanlah hanya ritualitas, namun agama berfungsi untuk menuntun keyakinan, memberikan ketentuan atau aturan berkehidupan serta membangun moralitas manusia. Oleh karena itu, agama diperlukan oleh manusia kapanpun dan dimanapun ia berada.

Kehidupan jiwa-raga (an-nafs) di dunia sangat penting, karena merupakan ladang bagi tanaman yang akan dipanen di kehidupan akhirat nanti. Apa yang akan diperoleh di akhirat tergantung pada apa yang telah dilakukan di dunia. Kehidupan sangat dijunjung tinggi oleh ajaran Islam, sebab ia merupakan anugerah yang diberikan Allah kepada hambanya untuk dapat digunakan sebaikbaiknya. Tugas manusia di bumi adalah mengisi kehidupan dengan sebaikbaiknya, untuk kemudian akan mendapatkan balasan pahala atau dosa dari Allah. Oleh karena itu, kehidupan merupakan sesuatu yang harus dilindungi dan dijaga sebaik-baiknya.Segala sesuatu yang dapat membantu eksistensi kehidupan otomatis merupakan kebutuhan, dan sebaliknya segala sesuatu yang mengancam kehidupan (menimbulkan kematian) pada dasarnya harus dijauhi.

Harta (mal) sangat dibutuhkan, baik untuk kehidupan duniawi maupun ibadah. Manusia membutuhkan harta untuk pemenuhan kebutuhan makanan, minuman, pakaian, rumah, kendaraan, perhiasan sekadarnya dan berbagai kebutuhan lainnya untuk menjaga kelangsungan hidupnya. Selain itu, hampir semua ibadah memerlukan harta, misalnya zakat-infak-sedekah-haji, menuntut ilmu, membangun sarana-sarana peribadatan, dan lain-lain. Tanpa harta yang memadai kehidupan akan menjadi susah, termasuk menjalankan ibadah.

Untuk dapat memahami ajaran agama dalam alam semesta (ayat kauniyah) dan al-Qur'an dan hadist (ayat qauliyah) manusia membutuhkan ilmu pengetahuan 
('ilm). Tanpa ilmu pengetahuan maka manusia tidak akan dapat memahami dengan baik kehidupan ini sehingga akan mengalami kesulitan dan penderitaan. Oleh karena itu, Islam memberikan perintah yang sangat tegas bagi seorang mukmin untuk menuntut ilmu.

Untuk menjaga komunitas kehidupan, maka manusia harus memelihara keturunan dan keluarganya (nasl). Meskipun seorang mukmin meyakini bahwa lingkup waktu kehidupan tidak hanya mencakup kehidupan dunia melainkan hingga akhirat, tetapi kelangsungan kehidupan dunia amatlah penting. Manusia akan menjaga keseimbangan kehidupan dunia dan akhirat. Oleh karena itu, kelangsungan keturunan dan keberlanjutan dari generasi ke generasi harus diperhatikan.Ini merupakan suatu kebutuhan yang amat penting bagi eksistensi manusia. $^{18}$

Beberapa literatur memang menjelaskan konsep kebutuhan dalam Islam dan melakukan pembagian dengan klasifikasi sebagai berikut, (1) kebutuhan primer (dharuriyyat), (2) sekunder (hajiyyat), dan (3) tersier (tahsiniyyat). Namun untuk yang untuk kebutuhan dalam tingkat kedua dan ketiga seringkali tidak dijelaskan secara riil contohnya. Disisi lain, jika dalam Islam telah disepakati bahwa manusia terdiri dari dua aspek yaitu jasmani (materil) dan rohani (spiritual) maka hal ini menjadi konsekuensi bahwa tugas para ekonom Muslim untuk mejelaskannya secara terang benderang bagaimana hierarki kebutuhan dalam aspek spiritual, meliputi kebutuhan primer, sekunder dan tersier.

Penulis menawarkan sebuah konsep kebutuhan dalam aspek rohani manusia sebagai berikut. Pertama, kebutuhan primer sebagaimana dijelaskan diatas. Merupakan tujuan untuk mencapai syariah (maqashid syariah) yang lima; agama, jiwa, harta, keturunan dan akal, ungkapan ini adalah apa yang dikatakan oleh alGhazali dan as-Syațibi dan sering dikutip oleh para ekonom Muslim dalam bahasan tentang kebutuhan, contohnya Umer Chapra.

Kedua, kebutuhan sekunder dalam aspek rohani manusia, menurut penulis adalah apa yang biasa disebutkan dalam al-Qur'an dengan al-fadlu. Mencakup hal ini ialah erat hubunganya dengan pengetahuan yang dimiliki seseorang ('ilm), dari pengetahuan yang dimiliki oleh seseorang inilah akan menjadikan seseorang tersebut menjadi ahli, pakar dan profesional (ar-rasikhuna fil 'ilmi) dalam urusan dunia.

Mengapa al-fadlu? Karena keahlian dan kepakaran seseorang merupakan aspek non materil yang tidak terlihat, akan tetapi sangat berguna bagi manusia -yaitu sebagai keutamaan diantara manusia yang lain, dengannya seseorang akan mendapatkan rezeki lebih banyak dibandingkan yang lain, ${ }^{19}$ dan juga diangkat derajatnya disisi Allah swt. ${ }^{20}$

\footnotetext{
${ }^{18}$ LP3EI, Ekonomi Islam, (Jakarta: Raja Grafindo Persada, 2008), 5-7

19 (QS. An-Nahl[16]: 71)

20 (QS. Al-Mujadalah[58]: 11)
} 
Selain itu, dengan keahlian yang dimiliki akan memudah seseorang untuk mengatur kewajibanya yaitu beribadah kepada Allah Swt. dengan artian, bahwa dia yang mengatur waktu sehingga kewajiban-kewajiban agama seperti shalat, puasa, zakat dan haji dapat dilaksanakan tanpa kekhawatiran akan kehilangan kesempatan untuk mendapat rezeki dari Allah yang berupa harta. Sebaliknya, tiadanya keahlian akan menyebabkan seseorang berusaha lebih keras dan bahkan dilakukanya tanpa mengingat waktu, implikasinya kewajiban-kewajibannya sebagai seorang hamba ('abdun) yaitu beribadah seringklai dilewatkan demi untuk mendapatkan harta. Disinilah mengapa al-fadlu menjadi kebutuhan sekunder dalam aspek spiritual manusia, yaitu guna memudahkan manusia untuk beribadah kepada Allah Swt.

Kebutuhan ketiga (tersier) dalam aspek rohani manusia adalah menghidupkan sunnah-sunnah Rasulullah. Hal ini desebutkan dalam firman Allah, "fatahajjad bihi nafilatan laka" -maka laksanakan shalat (sunnah) tahajjud sebagai tambahan untukmu. Dari firman Allah ini dijelaskan, bahwa fungsi ibadah-ibadah sunnah adalah sebagai penyempurna dari ibadah wajib yang dilaksanakan. Seperti halnya puasa-puasa sunnah sebagai penyempurna dari puasa wajib (ramadhan), begitupula sahur (ifthar) merupakan penyempurna (sunnah) dari ibadah puasa wajib, begitupula menikah adalah penyempurna dari separuh agama seseorang. Maka disinilah relevansi mengapa kebutuhan tersier dalam aspek rohani manusia adalah menghidupkan sunnah-sunnah Rasulullah saw.

\section{Konsep Kebutuhan dalam Islam (sebuah usulan)}

\begin{tabular}{|c|c|c|}
\hline \multirow{2}{*}{ Jenis Kebutuhan } & \multicolumn{2}{|c|}{ Aspek dalam diri manusia } \\
\cline { 2 - 3 } Tersier (tahsiniyyat) & Jasmani (materil) & Rohani (spiritual) \\
\hline Sekunder (hajiyyat) & mewah, motor & $\begin{array}{c}\text { Menghidupkan sunnah- } \\
\text { sunnah Rasulullah }\end{array}$ \\
\hline Primer (dharuriyat) & $\begin{array}{c}\text { SPP (sandang, pangan dan } \\
\text { papan) }\end{array}$ & $\begin{array}{c}\text { keahlian, profesionalitas } \\
\text { dll. }\end{array}$ \\
\hline
\end{tabular}

\subsection{Al-Adlu (keadilan)}

Keadilan merupakan nilai paling dasar dalam ajaran Islam, khusunya dalam bidang mua'malah. Menegakkan keadilan dan memberantas kezaliman adalah tujuan utama risalah para Rasululllah (QS.Al-Hadid[57]: 25). Pentingnya keadilan dalam ruang lingkup hubungan manusia dengan manusia lain (muamalah) menjadikan keadilan dekat atau bahkan sederajat dengan derajat ketakwaan (QS. Al-Ma'idah[ 5]:8). Ibnu Mandzur, membagi keadilan dalam empat dimensi; ${ }^{21}$ pertama, adil dalam menetapkan hukum. Kedua, adil dalam bilangan. Ketiga, adil

${ }^{21}$ Ibid, Ibnu Mandzur, Lisan al- 'Arab.., 2839 
dalam timbangan dan takaran (sama). Keempat, adil dengan menetapkan sesuatu yang berbeda dengan nilai yang sama. Dalam sejarah panjang perekonomian dalam peradaban Islam, keadilan ditempatkan sebagai nilai yang paling penting untuk diterapkan (maqashid). Semenjak pelarangan riba dan restu akan praktik jual beli (bai) yang diberikan oleh beliau kepada para sahabatnya, seraya berkata “'Amila ar-Rajulu bi Yadihi, Wa Kullu Bai'in Mabrur" -hasil kerja keras (seseorang) sendiri, dan segala transaksi (jual beli) bebas dari praktik penipuan (maysir, gharar dan riba).

Praktik penerapan keadilan juga dilakukan oleh para khulafa' ar-Rasyidun, sebagaimana khalifah 'Umar bin Khattab pernah 'berfatwa', 'La Yabi' fi Suqina illa Man Yufaqqih" -tidak ada orang yang melakukan transaksi jual beli, kecuali (dia) memahami hukum transaksi. Begitu pula ketika beliau 'ber-ijtihad' dengan merubah hukum harta rampasan perang dari ghanimah kepada fa' $i$, seraya berkata, "jika aku bagikan semua tanah rampasan perang ini, lalu apa yang akan kita berikan kepada generasi yang akan datang?"22 Pada umumnya, mayoritas ulama' terkemuka sepanjang sejarah peradaban Islam menempatkan kedilan sebagai unsur paling utama dalam kehidupan bernegara maupun bermasyarakat. Ibnu Taymiyyah misalnya menyatakan bahwa keadilan sebagai nilai utama dari tauhid. Sedangkan Muhammad 'Abduh menganggap kezaliman, antonim dari keadilan, sebagai kejahatan yang paling buruk (Aqbah al-Munkar) dalam nilainilai Islam. Sedangkan Sayyid Qutb menyebut bahwa keadilan sebagai unsur pokok yang komprehensif dan terpenting dalam semua aspek kehidupan.

Terminologi keadilan merupakan unsur komprehensif yang bermakna luas, meyusuri dalam segala aspek kehidupan antara manusia dengan manusia (mu'amalah).Oleh karena itu, terminologi ini memiliki terminologi turunan, yang dalam setiap konsep memiliki istilah yang berbeda meskipun intinya adalah satu makna yaitu keadilan. Zakiyuddin dalam Konsep Keadilan dalam Al-Qur'an menyatakan bahwa terminologi keadilan dalam al-Qur'an disebutkan dalam berbagai istilah, antara lain; al- 'adlu, al-qist, al-mizan, al-hiss, al-qashd. ${ }^{23}$

Istilah-istilah berdimensi Keadilan dalam al-Qur'an

\begin{tabular}{|c|ll|l|}
\hline $\begin{array}{c}\text { Istilah keadilan } \\
\text { dalam Al-Qur'an }\end{array}$ & \multicolumn{1}{c|}{ Definisi } & Dimensi \\
\hline & 1) & Persamaan balasan secara kuantitas & \\
Al-'Adl & 2) & Persamaan perlakuan secara kualitas & \\
& 3) & Persamaan hukum & Hukum \\
& 4) & Kebenaran, kejujuran dan proporsional & \\
& 5) & Tebusan dan penyucian & \\
\hline
\end{tabular}

${ }^{22}$ Abu Yusuf, Al-Kharaj,(Beirut: Dar al-Kutub 'Alamiyah, 1987), 150; Berbagai alasan lain dikemukakan oleh khalifah 'Umar bin Khattab mengenai ijtihad dalam hal ini, lihat: Rodney Wilson \& El Askher, Islamic Economic: A Short History, (Holland: Briil EJ, 2004), 102

${ }^{23}$ Zakiyuddin dalam LP3EI, Ekonomi Islam, (Raja Grafindo Persada, Jakarta, 2008), 60 


\begin{tabular}{|c|c|c|}
\hline Al-Qist & $\begin{array}{l}\text { 1) Adil dalam distribusi } \\
\text { 2) Adil dan proporsional dalam } \\
\text { bertindak }\end{array}$ & Distribusi \\
\hline $\begin{array}{l}\text { Al-Qashd, } \\
\text { (Iqtishad) }\end{array}$ & $\begin{array}{l}\text { 1) Berperilaku jujur dan lurus } \\
\text { 2) Berperilaku sederhana } \\
\text { 3) Berperilaku hemat } \\
\text { 4) Berperilaku berani } \\
\end{array}$ & Konsumsi \\
\hline $\begin{array}{l}\text { Qawwam, } \\
\text { (Istiqamah) }\end{array}$ & $\begin{array}{l}\text { 1) } \text { Berperilaku lurus } \\
\text { 2) } \text { Berperilaku jujur }\end{array}$ & Karakter \\
\hline Al-Hiss & $\begin{array}{l}\text { 1) Adil dalam distribusi } \\
\text { 2) Kejelasan dan terang benderang }\end{array}$ & Informasi \\
\hline Al-Mizan & $\begin{array}{l}\text { 1) Adil dalam timbangan (seimbang) } \\
\text { 2) Persamaan dalam balasan }\end{array}$ & Takaran \\
\hline Al-Washt & $\begin{array}{l}\text { 1) Moderat } \\
\text { 2) Tengah -tengah } \\
\text { 3) Terbaik, terpilih dan terpuji }\end{array}$ & $\begin{array}{c}\text { Politik dan } \\
\text { kemasyarakatan }\end{array}$ \\
\hline
\end{tabular}

\section{Kesimpulan}

Berdasarkan pemaparan diatas, dapat disimpulkan bahwa aplikasi konsep ta'dib dalam ekonomi Islam dapat dilihat berdasarkan konsep kunci dalam alQur'an yang berkaitan dengan kegiatan atau aktivitas ekonomi. Antara lain alfadlu, 'adl, maslahah, iqtishad, dan falah. Dengan adanya konsep-konsep kunci ini, diharapkan pengajaran dalam ekonomi syari'ah dapat mencapai tujuan yang diharapkan oleh Islam -yaitu mencapai manusia yang baik perilakunya (insan alkamil) yang menggunakan keutamaannya dan kekayaannya didunia untuk akhirat demi mendapatkan ridho Allah Swt (ibtigha'i wajhi Allah). Wallahu A'lam bisshowab.

\section{Daftar Pustaka}

Ahmad, Ja'far et, al. 2011. Ekonomi Islam: Suatu Pendekatan Analisis. Bangi: UKM Press.

Boayo, Sulaiman MH. Idea of Thaqafah and Culture in the Muslim dan Western Conception, World Journal of Islamic History and Civilization, Vol. 1 No.2, 2011

Byarwati, Anis. \& Tjiptohadi, Ekonomi Islam atau Iqtishad?, Jurnal Ekonomi, Manajemen dan Akuntansi Islam, Vol.1, No.1, 2013

Chapra, M. Umer. 2001. Masa Depan Ilmu Ekonomi: Sebuah Tinjauan Islam, terj. Ikhwan Abidin Basri. Jakarta: Geman Insani Press.

Daud, Wan Mohd Nor Wan. 2003. Filsafat dan Praktik Pendidikan Islam Syed Naquib Al-Attas, terj. Hamid Fahmy dkk, Cet.I. Bandung: Mizan.

http://www.britannica.com/topic/economics. diakses, Senin, 09 Nopember 2015, $13: 10 \mathrm{wib}$

LP3EI. 2008. Ekonomi Islam. Jakarta: RajaGrafindo Persada. 
Mandzur, Ibnu. (t.t.). Lisan al-'Arab. tahqiq. 'Abdullah 'Ali al-Kabir et, al. Qahirah: Dar al-Ma'arif Li an-Nasyr.

Ruslan, Abidin Ibn. 1998. Pemikirian al-Ghazali Tentang Pendidikan. Cet.I. Yogyakarta: Pustaka Pelajar.

Wilson, Rodney \& El Askher. 2004. Islamic Economic: A Short History. Holland: Briil EJ.

Yusuf, Abu. 1987. Al-Kharaj. Beirut: Dar al-Kutub ‘Alamiyah. 